\title{
Abraão e o Absurdo - Dos \\ olhares da fé e da razão quedada
}

\section{Abraham and the Absurd - From \\ the looks of faith and fallen reason}

Jimmy Sudario*

\section{Rafael de Castro Lins}

Arquivo recebido em

26/04/2016

e aprovado em

03/07/2016.

V. 6 - N. $11-2016$

* Professor do

Departamento de Ciências da Religião da Universidade

Federal de Juiz de Fora (UFJF). Doutor em Teologia pela PUC-RJ. Email: sudarioc@hotmail.com.

** Mestrando em Ciência da Religião pela Universidade Federal de Juiz de Fora.

Email: rafaelcastro. teologia@gmail.com. 
tocadas ligeiramente neste artigo.

Palavras-chave: Temor e Tremor, Suicídio filosófico, Crítica à razão, Mito de Abraão, Caim.

\section{Abstract}

Considering the existential deepening belonging to the biblical narrative of Abraham's myth, Kierkegaard, besides focusing on the medullary meaning of this story, also makes several outlines through which that dramatic act may be seen. This article attempts on these assumptions of the work Fear and Trembling, correlating and confronting the philosophical thought of Albert Camus, regarding aspects of faith, ethics, and Christian metaphysics. To achieve this, Camusian's privileges such as the philosophical suicide were emphasized from Camus' own comments about what had preceded, along an extensive tradition on criticism to modern reasoning, Kierkegaard. Meanwhile, a Camusian perspective over Abraham's myth had been illustrated under the light and support of José Saramago's novel Cain. This way, pervading between Fear and Trembling, the Myth of Sisyphus, and Cain, three different shades of perception of Christian metaphysics were slightly brushed over this article.

Key words: Fear and Trembling, philosophical suicide, Critical reason, Myth of Abraham, Cain.

\section{I- Introdução - Herdeiro do pensamento humilhado}

Ibert Camus não arroga para si o conceito de Absurdo, longe disso, ele o procura avidamente naqueles que o antecedem, como em Kierkegaard. Não obstante sua contribuição mais original não seria apenas reconhecer o Absurdo na existência, ou em diversos autores consagrados do existencialismo, sua ousadia consiste precisamente em não negá-lo, não perdê-lo de vista nas veredas do suicídio. Seu pensamento o torna notável por resistir ao salto metafísico, empenhado na descoberta dos limites do homem absurdo uma vez lançado nestes desertos da existência - sob os escombros da razão e privado dos consolos da fé.

Herdeiro de uma longa tradição de crítica ao racionalismo, Camus se situa sobre as ruínas da razão quedada. O que Camus chama de "a tra- 
dição do pensamento humilhado" (CAMUS, 2013a, p. 35) permaneceu ainda mais viva depois das duas grandes guerras do século XX. Neste ínterim de crítica da razão, a perspectiva camusiana conota uma considerável influência do pensamento kierkegaardiano. Adiante, Camus tece alguns comentários sobre Kierkegaard, em O Mito de Sísifo, para demonstrar neste a concepção do Absurdo da existência e para exemplificar o que Camus compreende como Suicídio Filosófico.

A comunhão temática existente entre Camus e Kierkegaard, assim como a influência literária deste último sobre Camus, torna possível aproximar para observação as suas distintas compreensões acerca da fé. Para tanto, a história bíblica do mito de Abraão nos serve aqui como paisagem comum para confrontar dois olhares que divergem sobre as implicações éticas desta narrativa. A saber, duas perspectivas foram retiradas desta mesma história milenar que narra origem do povo hebreu: ou Abraão era um crente ou um louco assassino. Enquanto Kierkegaard aventura-se em explicar a natureza incognoscível desta fé abraâmica, Albert Camus e José Saramago apostam no crime de Abraão.

\section{II- Do suicídio de Kierkegaard - Um olhar camusiano}

A respeito dos pensadores do irracional, testemunhas do Absurdo, a Camus interessa a concordância existente entre eles sobre o tema. Entretanto, nota em alguns deles formas de evasão ante o Absurdo, ou seja, Camus observa "fugas metafísicas", de cunho filosófico ou religioso, presentes em estimados autores da filosofia existencial, como Jaspers, Kierkegaard, Chestov e Husserl. Tais "fugas" ele chama de suicídio filosófico. ${ }^{1}$

Para chegar ao suicídio filosófico, o caráter contraditório do Absurdo deve ser acentuado. Camus atenta que o Absurdo nasce da desproporção entre as intenções do homem e a indiferença do mundo sob o qual

1. Cf. "O Suicídio Filosófico" em CAMUS, Albert. O mito de Sísifo. $3^{a}$ edição. Rio de Janeiro: BestBolso, 2013a, p. 39-57. 
ele fora jogado para existir. No mais, essa premissa se torna fundamental para que se possa pensar no Absurdo como confrontação, nem presente no homem e nem no mundo, mas no choque entre eles. Camus não tece uma definição mais concreta do Absurdo, ele contenta-se em, ao longo de seus ensaios, enumerar sentimentos do Absurdo e realçar o tônus deste estado, como nesta passagem a seguir:

É um exílio sem solução, porque está privado das lembranças de uma pátria perdida ou da esperança de uma terra prometida. Este divórcio entre o homem e sua vida, o ator e seu cenário é propriamente o sentimento do absurdo (CAMUS, 2013a, p. 21).

Camus se atém a filosofia existencial, e nela encontra formas de "fuga" do Absurdo por meio de uma evasão essencialmente religiosa, a seu ver. A filosofia existencial de seu tempo visitou atentamente os escombros da razão, todavia não soube o que reconstruir sobre esse mundo despedaçado da modernidade e, assim, aventurou-se a procura de "esperanças forçadas". E nesta procura, o pensamento chocado com a absurdidade da vida, de repente nega a si mesmo, nega por completo a razão humana, e salta aspirando ao eterno (CAMUS, 2013a, p. 50).

A título de exemplo, Camus evidencia que o suicídio filosófico incorre no erro de divinizar, por vez, o irracional ou a própria razão. Sob os muitos disfarces modernos o Absurdo continuava a ser negado, ou nas palavras do próprio Camus: "Assim como a razão soube aplacar a melancolia plotiniana, ela fornece a angústia moderna os meios de se acalmar nos cenários familiares do eterno" (CAMUS, 2013a, p. 55).

Nesta apreciação camusiana, Kierkegaard fora o exemplo mais toante de "suicida filosófico" por render-se estupefato - levado por intensa atração - ao fascínio incomensurável do irracional. Também para Kierkegaard, nota O Mito de Sísifo, "a antinomia e o paradoxo se tornam critérios do religioso. [...] O cristianismo é o escândalo e o que Kierkegaard pede com simplicidade o terceiro sacrifício exigido por Inácio de Loiola, aquele com que Deus mais se delicia: 'o sacrifício do 
Intelecto'" (CAMUS, 2013a, p. 47).

Não são espíritos rasos, ou indoutos, aqueles que resignaram a razão para oferecê-la num abnegado sacrifício, são antes espíritos absurdos consumidos impiedosamente pela natureza antinômica da existência - e dela tentam escapar. No ver desassossegado de Camus, uma adesão incondicional e resignada a esta condição absurda calou - com mordaças metafísicas - o grito da revolta, tão necessário diante deste quadro paradoxal da existência. A inquietação camusiana nasce deste lanço descabido e apaixonado em direção do irracionável - ou como bem explicita Gouvêa nesta "paixão pelo paradoxo". ${ }^{2}$ Este título toca no ponto fontal do pensamento kierkegaardiano que, pelas palavras de Camus, "arranca sua esperança do seu contrário, que é a morte" (CAMUS, 2013a, p. 48), e assenta sobre o este insolúvel paradoxo toda uma elevação que se encerra em Deus.

Em subida pelo monte Moriá, o mito de Abraão exemplifica esta jornada que leva ao irracional - uma subida de fé movida por um ato deveras inexplicável em termos éticos ou racionais. Abraão caminhou para sacrificar o filho, e na adesão incondicional a esta loucura inconcebível consistiu à força da sua fé - é nas veredas do absurdo que Deus labora o cavaleiro da fé. A esse respeito Camus coloca: "Se substituir seu grito de rebeldia por uma adesão furiosa, ele será levado a ignorar o absurdo que o iluminava até então e a divinizar a única certeza que daí por diante terá: o irracional" (CAMUS, 2013a, p. 47-48).

Fugir do Absurdo, diria Camus, é vê-lo divino. Maquiar Deus com as aparências obscuras do irracional e caminhar cegamente ao seu encontro, levado pela força do absurdo - sob os escombros da razão e a inobservância da ética - esta é a jornada do cavaleiro da fé. A improvável esperança abraâmica forçosamente esperou recuperar Isaac depois de sacrificá-lo e, a despeito do fim desta história, a fé de Abraão

2. Cf: GOUVÊA, Ricardo. Paixão pelo paradoxo: uma introdução a Kierkegaard. São Paulo: Novo Século, 2000. Este título que Ricardo Gouvêa dera ao seu livro ilustra, em termos de síntese, a relação kierkegaardiana entre a razão e a fé. 
também exigiu dele o sacrifício do seu intelecto - posto mortalmente ao lado de Isaac. Isaac não seria sacrificado sozinho, em silêncio às alturas do Moriá, Abraão ofereceu ainda sua lucidez. Ou ainda, nas palavras camusianas, Abraão cometera suicídio filosófico.

Aliás, o único ato lógico de Abraão era reagir ao ditame de Deus. Revoltar-se até a rouquidão de tanto negar aos céus aquela vontade absurda. E nesta negação do absurdo consiste a revolta camusiana, se corporifica na resistência humana à loucura divina que impele o pai contra seu filho - não na adesão incondicional a este destino absurdo que os deuses quiseram. Camus prefere a tragédia de Édipo à reconciliação de Abraão, a fuga furiosa da soberania dos deuses - ainda que esta seja inútil - à adesão apaixonada ao despotismo de um Deus.

Contrário à fé movida pela força do Absurdo, Camus assevera: "O absurdo, que é o estado metafísico do homem consciente, não conduz a Deus" (CAMUS, 2013a, p. 49). O Absurdo é antes uma condição ignóbil de um homem consciente das fronteiras da razão, lançado em um mundo opaco, inexplicável senão por raciocínios errôneos - e neste "universo repentinamente privado de ilusões e de luzes, pelo contrário, o homem se sente um estrangeiro" (CAMUS, 2013a, p. 21). Todavia, retoma ele, o engano está em afeiçoar-se ao Absurdo, como a vítima que se afeiçoa ao seu agressor. O que excede a lucidez é enxergar-se acolhido neste sequestro da existência, nesta falsa pátria, "e me asseguram [pontua Camus] que essa ignorância explica tudo e que essa noite é a minha luz. Mas aqui não respondem à minha intenção e esse lirismo exaltante não pode me esconder o paradoxo" (CAMUS, 2013a, p. 49).

Sobre Kierkegaard, Camus acentua o empenho desvairado desta inteligência em subtrair-se do caos antinômico em que fora posto, e do desespero a ele inerente, paradoxalmente recorrendo - lançando-se confiadamente - ao irracional. À vista disso, da irracionalidade desta vida, o rosto de Deus é rascunhado por Kierkegaard - e descrito pela força do mito na narrativa abraâmica - com os atributos do incompreensível, 
da injustiça e da inconsequência (CAMUS, 2013a, p. 48). Entrementes, quando se dedica a expor a falta de razoabilidade do sacrifício de Isaac, o trunfo kierkegaardiano é pô-lo para além das medidas humanas, acima da linha que separa o ético-racional dos campos verdes da fé. Camus, porém, assegura que as medidas humanas são as únicas que aos homens foram dadas. Afinal, os homens não são Cristos: "todo meu reino é deste mundo" (CAMUS, 1996, p. 107). Camus, confundindo Deus propositalmente com a paixão pelo irracional, pondera sobre os limites da razão:

Não depreendo daí uma negação, mas ao menos não quero fundamentar coisa alguma no incompreensível. Quero saber se posso viver com o que sei, e só com isso. Dizem-me ainda que a inteligência deve sacrificar aqui o seu orgulho e a razão, se inclinar. Mas se reconheço os limites da razão, nem por isso a nego, reconhecendo seus poderes relativos. Só quero continuar neste caminho médio onde a inteligência pode permanecer clara (CAMUS, 2013a, p. 49).

\section{III- No Lugar de Abraão}

Dois espíritos do século sopravam ventanias. Kierkegaard fazia longos retornos às narrativas germinais dos textos bíblicos. Buscava atualizá-las para seus dias. Ele rememorou tais histórias, fora buscar nas origens, no gênese, sentidos esquecidos a termos já há muito esvaziados de significado - tal como a fé - para uma Dinamarca protestante do século XIX, cuja religião tornara-se outro hábito insípido do cotidiano burguês. Poucos anos depois, em terras alemãs e luteranas, Nietzsche proclamava em pleno meio-dia - demasiadamente louco com uma lanterna nas mãos - a "Morte de Deus". Mesmo sem anunciá-la explicitamente, Kierkegaard lera a Morte de Deus também nos vitrais da igreja protestante ao perguntar pelo lugar de importância da fé entre as muitas preocupações do sujeito protestante dinamarquês - como diria Nietzsche mais tarde: "O que são estas igrejas além de túmulos e monumentos funerários de Deus?" (NIETZSCHE, 1978, p. 125). 
A obra kierkegaardiana provoca confessos cristãos e revela os frágeis limites da sua fé, ou de outra, inquire pelo preço barato da fé na modernidade. Como em Temor e Tremor, quando através da radicalidade abnegada do sacrifício de Abraão, Kierkegaard questiona até onde se está realmente disposto a ir, e a sacrificar, quando se está numa relação de fé absoluta. Temor e Tremor retorna aos dias de Abraão e, quando de volta à Copenhague cristã do século XIX, torna clara a fragilidade de uma fé sem paixão, fronteiriça - indisposta à incondicionalidade. Kierkegaard não só assumira a morte de Deus, como se esforçou em revelá-la no dia a dia de seus contemporâneos. E, antes de propor uma vereda de sentido sob as inspirações da fé cristã, antes do salto, o filósofo chama atenção à perigosa realidade de uma existência estética de aparência religiosa, e por assim dizer também anuncia - como um profeta nietzschiano - que igrejas entoam, ainda que despercebidas, o lúgubre funeral de Deus.

Herdeira da Renascença, a reforma protestante também erigiu sua fundamentação doutrinária no retorno às fontes. E em seus embates contra o catolicismo, a igreja protestante encontrou nas escrituras bíblicas a autoridade e legitimação que Ihe faltava. Depois de séculos de expansão e estruturação, Kierkegaard empreendeu no seio do protestantismo dinamarquês um retorno semelhante ao da reforma, trouxe de volta as escrituras interpretando-as novamente, desta vez visando afetar a apatia religiosa, a fé marginal e condicionada, do fiel protestante. Nestes vieses, a obra Temor e Tremor se movimenta em direção à história primeva do patriarca Abraão, especialmente a esta passagem medular:

Passado algum tempo, Deus pôs Abraão à prova, dizendo-lhe: "Abraão!" Ele respondeu: "Eis-me aqui". Então disse Deus: "Tome seu filho, seu único filho, Isaque, a quem você ama, e vá para a região de Moriá. Sacrifique-o ali como holocausto num dos montes que Ihe indicarei" (Gn 22. 1-2).

Às voltas com seus personagens literários de personalidade própria, 
Kierkegaard mergulhou na narrativa abraâmica sob seu pseudônimo, Johannes de Silentio. O pseudônimo Ihe permitiu, de certa forma, adentrar nesta história de modo impetuoso, ou seja, Kierkegaard caminha com facilidade entre o elogio à fé de Abraão e os problemas ou questões que nascem com uma leitura atenta à narrativa. Problemas estes, por um lado, normalmente ignorados em virtude da sacralidade ou desatenção ao texto, e por outro lado acessados com mais liberdade para pô-los em evidência - um sintoma moderno que impele ao direito e o dever de duvidar da tradição. Neste ínterim, Kierkegaard constrói diversas perspectivas - com o atrevimento literário que o distingue à parte dos exegetas - sobre esta passagem fundamental em que Abraão foi posto à prova pelo próprio Deus.

Kierkegaard compôs detalhes e possibilidades imaginativas para a jornada de Abraão, desde que fora posto à prova até o momento decisivo do sacrifício, quando levantou a faca contra seu próprio filho.

No primeiro reconto de Kierkegaard - com a riqueza literária que lhe é peculiar - ele ressaltou o mutismo de Abraão ao longo da trajetória que o levava ao monte Moriá, lugar que sacrificaria Isaac. Nas entrelinhas da narrativa bíblica, ele especulou a saída encontrada por Abraão frente aquele ato monstruoso que estava prestes a cometer. Ao chegar ao lugar indicado, o pai aterrorizou o filho expondo seu desejo e seu prazer naquele ato. Assim Abraão reguardou Deus do ódio de Isaac: "Murmurou porém Abraão dizendo para consigo: 'Senhor nas alturas, graças te dou; bem melhor é que acredite que eu sou um monstro do que a vir perder a fé em Ti” (KIERKEGAARD, 2009, p. 59).

A leitura pronta, carregada de interpretações pré-estabelecidas, sem o trabalho devido e atencioso do texto é indesejável na opinião de Kierkegaard (KIERKEGAARD, 2009, p. 81). Isto presumivelmente explica o tempo que dispõe em considerar, e especular, as variantes nascidas das entrelinhas desta história bíblica, tal como o provável ódio que no coração de Isaac nasceu ao ouvir de seu pai a ordem que Deus Ihe impu- 
tou. Qualquer sensibilidade mínima pensaria na monstruosidade daquela ordem. Fora realmente crível tal possibilidade, esta que Deus, em algum instante daquela história, tornou-se um monstro aos olhos de Isaac.

No segundo reconto de Kierkegaard, Abraão não revela a Isaac a ordem de Deus. Tudo ocorrera em silêncio. O pai apenas lembrava o quanto amava Isaac, seu significado, o quanto lhe custava um ato tal como aquele, sacrificá-lo. Entretanto, Abraão foi até o fim, puxou a faca sobre seu filho, quando viu então o cordeiro que o aliviaria daquele fardo. Isaac permanecera vivo, tudo foi apenas um teste. Porém, nesta versão kierkegaardiana da história, Abraão perdera toda a alegria de viver, pois "Daquele dia em diante Abraão envelheceu, não conseguia esquecer o que Deus dele exigira" (KIERKEGAARD, 2009, p. 60).

Ir além do texto, sem medo do labor implicado nesta ida, é também considerar o quanto valia Isaac para existência de Abraão, o lugar especial que aquele filho prometido assumira, e a substância da vida de Abraão, nele, representada. A possibilidade de perdê-lo - por suas próprias mãos - poderia de fato afetar Abraão pelo resto de sua vida. A dor seria ainda maior a cada encontro da memória com aquela lembrança terrificante, Deus lhe exigira a morte do seu filho amado.

O terceiro reconto de Kierkegaard se passa após Abraão ter puxado a faca. Isaac não fora sacrificado, mas Abraão pensou no seu dever como pai, por isso pediu a Deus que lhe perdoasse "o pecado de ter querido oferecer Isaac em holocausto" (KIERKEGAARD, 2009, p. 61). No entanto, Abraão pensou outra vez, conclui que não lhe faltava amor para com seu filho, e se porventura esse amor houvesse faltado, seu pecado seria de sobremodo imperdoável.

Kierkegaard prossegue ao longo de Temor e Tremor favorável a esta hipótese, pois não equipara Abraão a um pai de hediondo desapego, ao invés, dar-se a entender que Isaac era toda a vida de Abraão, posta ali, em sacrifício.

No quarto e último reconto de Kierkegaard, os detalhes tornam a 
narrativa vívida, de um modo a afetar o seu leitor com o desespero de Abraão que o fizera contorcer-se no último instante em que o filho via a morte pela faca do pai. Tudo se passou bem como se sabe, mas "Isaac havia perdido a fé" (KIERKEGAARD, 2009, p. 63).

Esta conjectura sobre as reverberações daquele momento desesperador coloca o leitor sob o olhar de Isaac, no lugar da vítima. Também transparece o profundo desespero de Abraão, torturado pelo amor ao filho que, porém, não sobrepunha a sua fé absoluta e incondicional.

Cada hipótese rememora a talvez esquecida profundidade, ou complexidade, do ato de Abraão, as ressonâncias daquela assustadora atitude para vida de ambos, pai e filho, verdugo e vítima. Tal ato não pode ser lido, sem por ele ser afetado.

\section{IV- Camus e Caim}

Albert Camus de certo lera cada uma destas especulações, ele não deixou por escrito o quanto fora afetado por elas ou a sua versão da história de Abraão, somente em breves passagens fez alusão à narrativa abraâmica original. Porém, Camus respondeu ao pensamento de Kierkegaard contrapondo o ponto fundante de sua filosofia, o salto de fé kierkegaardiano. E por sobre este encontro intencional de Camus e Kierkegaard poder-se-á inferir a perspectiva camusiana sobre o drama de Abraão, assim como notar pontos de ruptura e de retorno entre estes dois autores. Kierkegaard declara:

Se no homem não houvesse uma consciência eterna, se na origem de tudo se encontrasse apenas uma força bravia e lêveda que ao contorcer-se em escura paixão tudo criasse, o que fosse grande e o que fosse insignificante; se um vazio sem fundo, nunca saciado, sob tudo se escondesse, que outra coisa seria a vida a não ser o desespero? (KIERKEGAARD, 2009, p. 112)

Camus sem furtos responde a Temor e Tremor. 
Kierkegaard pode gritar [...] Este grito não pode deter o homem absurdo. Buscar o que é verdadeiro não é buscar o que é desejável. Se, para fugir da pergunta angustiante: "o que seria então a vida?", é preciso alimentar-se, como o asno, das rosas da ilusão antes que se resignar à mentira, o espírito absurdo prefere adotar sem tremor a resposta de Kierkegaard: "o desespero" (CAMUS, 2013a, p. 50).

Assumir a retórica de Kierkegaard sem o devido tremor apregoado pela obra, como Camus o faz, é uma posição de enfrentamento ao argumento kierkegaardiano. Nascido quase precisamente um século depois de Kierkegaard, Camus fora de fato um herdeiro do lastro existencialista legado pelo filósofo dinamarquês, isto o possibilitou absorver as intuições kierkegaardianas no que toca a existência e, imerso neste discurso, renunciar a etapa que cruza as fronteiras da razão e repousa na guarida da fé. Em outras palavras, Camus acompanha Kierkegaard na decisiva e necessária superação do estético e na passagem para o ético, todavia hesita frente o "salto de fé", o lanço no estágio religioso da existência.

Conforme as orientações de Gouvêa ${ }^{3}$, o feito de Abraão explicita a passagem do ético ao religioso, o movimento de fé particular que relativiza o universal. Ou, nas próprias considerações de Kierkegaard: "Através

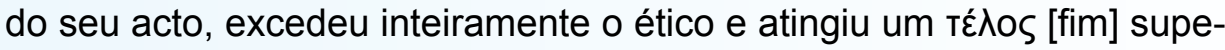
rior fora dele, em relação ao qual suspendeu o ético" (KIERKEGAARD, 2009, p. 118).

Na determinante suspensão do ético reside o drama de Abraão, não se pode negar a centralidade desta escolha, nem os juízos que dela suscitam. Ora, aos olhos de um viajante qualquer, de passagem justamente quando a faca luziu não permitindo dúvidas sobre o que ocorreria, Abraão fora outro pai ignóbil, sanguinolento, à imagem do demônio a quem obedecia cegamente. Todavia, a igual privação ética que o faria deveras imperdoável o fez também, reconhecidamente, o pai da fé.

3. Cf: GOUVÊA, Ricardo. Paixão pelo paradoxo: uma introdução a Kierkegaard. São Paulo: Novo Século, 2000. 
Visto dos ares religiosos da existência, mais do que qualquer pai Abraão amava seu filho, pois o não amá-lo desfaria assim o valor do sacrifício, e nisto consiste a grandiosidade do seu ato. Visto do chão pueril de um transeunte qualquer, Abraão estava prestes a sujar-se com o sangue do seu filho e nada nesse mundo poderia justificá-lo.

Camus, ainda consternado pelos horrores do século das grandes guerras mundiais, labora sua obra como amparo intelectual de absoluta negação ao assassinato justificado, seja ele um construto político, religioso ou étnico - Camus nunca esquecera o odor putrefato dos campos de concentração nazista, ou os pressupostos religiosos que historicamente legitimaram o assassinato. De certa forma seria dizer que a versão camusiana do mito abraâmico, presumivelmente, conotaria uma blasfema recusa à fé, ou à salvação, em nome de um valor moral, como o fez Ivan Karamázov antes dele, no emblemático romance de Dostoiévski. Confundindo suas próprias palavras com a revolta metafísica de Ivan, Camus acentua sua recusa à fé, se esta pressupõe a suspensão do ético ou a aceitação do mal. Ele comenta:

Ivan recusa explicitamente o mistério e, por conseguinte, o próprio Deus como princípio de amor. Só o amor pode nos fazer ratificar a injustiça feita a Marta, aos operários das dez horas, e, mais adiante, admitir a morte injustificável das crianças. "Se o sofrimento das crianças", diz Ivan, "serve para completar a soma das dores necessárias à aquisição da verdade, afirmo desde já que essa verdade não vale tal preço" (CAMUS, 2013b, p. 75).

A morte de Isaac seria de certo um preço alto demais como condição à fé, neste ínterim. E qualquer outro expectador que não seja Deus, imediatamente - diante daquele cenário de terror - ao ouvir o grito de Isaac se poria em favor da pobre vítima. Através de seu herói de A Peste o doutor Rieux, entre o sacerdote e o cordeiro do sacrifício Camus confessa sua escolha: "Sinto-me mais solidário com os vencidos do que com os santos" (CAMUS, 2013c, p. 222). Talvez outra perspectiva, narrada recentemente, melhor se adequaria, ou melhor representaria a versão 
camusiana deste mesmo mito fundante.

José Saramago não escondeu seu ateísmo, ou sua indignação frente os ditames arbitrários e antiéticos de Deus, como a bíblia os conta. Seu romance Caim o insere no universo sagrado das narrativas do Primeiro Testamento, como alguém disposto a perturbar tais histórias, contorcê-las, de modo a recontá-las da maneira mais herética possível. Seu fim é revelar o verdadeiro caráter genocida do Deus bíblico, assim como a substância amoral que constituí esse tipo de literatura canônica.

A versão de Saramago segue em linhas gerais o mito bíblico, todavia o personagem Caim adentra, como um intruso rebelde, à história de Abraão. Como Kierkegaard também o fez, Saramago recorda a ordem divina e reescreve as entrelinhas desta história:

O leitor leu bem, o senhor ordenou a abraão que lhe sacrificasse o próprio filho, com a maior simplicidade o fez, como quem pede um copo de água quando tem sede, o que significa que era costume seu, e muito arraigado. O lógico, o natural, o simplesmente humano seria que abraão tivesse mandado o senhor à merda, mas não foi assim (SARAMAGO, 2009, p. 79).

Abraão já havia deitado o filho sobre o altar, obediente aos céus, estava prestes a corta-lhe a garganta, quando um anjo segurou-lhe ferozmente o braço dizendo:

Que vai você fazer, velho malvado, matar o seu próprio filho, queimá-lo, é outra vez a mesma história, começase por um cordeiro e acaba-se por assassinar aquele a quem mais se deveria amar, Foi o senhor que o ordenou, foi o senhor que o ordenou, debatia-se abraão, Cale-se, ou quem o mata aqui sou eu, desate já o rapaz, ajoelhe e peça-lhe perdão, Quem é você, Sou caim, sou o anjo que salvou a vida a isaac (SARAMAGO, 2009, p. 80).

Pelas mãos de Caim - o primeiro homicida - José Saramago impedira Abraão, na tentativa de recobrar-Ihe a decência digna de um pai. Seu abuso das entrelinhas do texto soa como um desafio à ordem divina. Ele 
enfim disse o sonoro "não" aos céus, aquele que Abraão não conseguira dizer. Sua ousadia imagina os diálogos entre pai e filho, depois daquela interrupção oportuna de Caim. Isaac não compreende porque o pai quisera matá-lo, Abraão justifica-se alegando que a ideia foi do Senhor, pois queria por em prova a sua fé. Isaac compreende menos ainda a ordem de Deus:

$E$ que senhor é esse que ordena a um pai que mate o seu próprio filho, É o senhor que temos [...] E se esse senhor tivesse um filho, também o mandaria matar, perguntou isaac, O futuro o dirá, Então o senhor é capaz de tudo, do bom, do mau e do pior (SARAMAGO, 2009, p. 82).

Isaac continua a interrogar Abraão a respeito do Deus que the pedira tamanho absurdo. Abraão persuade o filho a esquecer daquele ignóbil ocorrido, o jovem porém não se julga capaz de tal feito - ainda revia a faca a luzir e o seu corpo imóvel atado aquele destino -, poderia a vítima esquecer-se do seu algoz? Saramago redefine aquela história, vista desta vez pelos olhos da vítima, diz Isaac: "Pai, a questão, embora a mim me importe muito, não é tanto ter eu morrido ou não, a questão é sermos governados por um senhor como este, tão cruel como baal, que devora os seus filhos" (SARAMAGO, 2009, p. 83).

Como aquele que herda muito de quem o antecede, Saramago compartilha com Camus um mesmo olhar, de lentes éticas, quando ambos olham para o Deus das escrituras judaico-cristãs. Eles também se opõem, ou ignoram, a perspectiva kierkegaardiana que atribui virtude no ato sacrifical de Abraão. Quando Caim - como um anjo - salva a vida de Isaac, ele o faz, pois, até aquele momento, Deus não o fizera. O sofrimento daquele pai e daquela criança era assistido passivamente por Deus. Todavia, o fim da história testemunha em favor de Deus e, embora um mistério sombrio - um silêncio torturante - reinasse antes do fim, Isaac não seria sacrificado por mero capricho divino. A intervenção de Caim fora sua impaciência contra os céus - e esse seu mistério sádico. Ele assim o diz em conversa com anjos: 
Os desígnios de deus são inescrutáveis, nem nós, anjos, podemos penetrar no seu pensamento, Estou cansado da lengalenga de que os desígnios do senhor são inescrutáveis, respondeu caim, deus deveria ser transparente e límpido como cristal em lugar desta contínua assombração, deste constante medo, enfim, deus não nos ama (SARAMAGO, 2009, p. 135).

Camus, de igual modo, recusa-se a resignação diante do mistério infligido, ou da paciência que assiste o sofrimento dos homens passivamente. Como Caim ele se opõe à morte justificada, segura o braço direito de Abraão com violência indignada sem aguardar pelos anjos celestes - pois eles frequentemente se atrasam. ${ }^{4}$ Caim, quando enfrenta Abraão, encena como por parábolas o conceito camusiano de Revolta. Em solidão metafísica, que Deus Iho impôs, Caim contesta a morte de Isaac sem sequer olhar para os céus. Camus - como quem já fizera o mesmo alhures - também o diz recorrendo a seu romance $A$ Peste: "Já que a ordem do mundo é regulada pela morte, talvez convenha a Deus que não acreditemos Nele, e que lutemos com todas as nossas forças contra a morte, sem erguer os olhos para o céu, onde Ele se cala" (CAMUS, 2013c, p. 115).

Outra vez comentando Dostoiévski, Camus assevera: "A fé conduz à vida imortal. Mas a fé pressupõe a aceitação do mistério e do mal, a resignação à injustiça" (CAMUS, 2013b, p. 75). Quando Camus estabelece, à sombra de Ivan Karamázov, a oposição entre Deus e a Justiça retorna às inspirações kierkegaardianas de necessidade de superação do estágio ético pelo religioso. Camus ou Caim tomam o partido dos homens, ou seja, elevam a ética acima da divindade. A existência assim se inverte na necessária passagem, desta vez, do religioso para o ético e não o contrário. Saramago, por sua vez, alça além, não apenas ergue a justiça e diminui a divindade, mas ele também condena o Deus bíblico

4. Depois que Caim interrompera o sacrifício, um anjo enviado por Deus pousa, atrasado, no monte Moriá trazendo a mensagem que Isaac não precisava mais ser sacrificado e que aquilo nada mais era do um teste de fé. Cf: SARAMAGO, José. Caim. São Paulo: Companhia das Letras, 2009, p. 80. 
pelas próprias medidas da justiça. Caim continua a esbaforida conversa com os anjos, e arrota seus juízos contra Deus:

Sobretudo quando manda matar, uma só criança das que morreram feitas tições em sodoma bastaria para o condenar sem remissão, mas a justiça, para deus, é uma palavra vã, [...] Cuidado, caim, falas de mais, o senhor está a ouvir-te e tarde ou cedo te castigará, $\mathrm{O}$ senhor não ouve, o senhor é surdo, por toda a parte se lhe levantam súplicas, são pobres, infelizes, desgraçados, todos a implorar o remédio que o mundo lhes negou, e o senhor vira-lhes as costas (SARAMAGO, 2009, p. 135-136).

Saramago transparece nitidamente intuições camusianas nestas palavras citadas, precisamente no que toca o mutismo divino contraposto diante da agonia dos miseráveis desta terra, perturbados pela morte e pelo sofrimento. O Absurdo, como Camus o entendia, consiste exatamente nessa realidade nascida do remédio que os homens imploram, a cura que o mundo Ihes nega, e a indiferença do Deus que virou-lhes as costas. De maneira axiomática - por serem contemporâneos - estes dois autores refletem os sintomas de um mundo pós-guerras e caminham juntos sobre os escombros da razão moderna. Partilham da mesma sombra pessimista que varreu a Europa naquele século, e do mesmo céu trevoso de onde Deus, silenciosamente, assiste o sofrimento dos homens. Camus e Saramago foram aparentados por sua revolta e, de certo, uma versão camusiana do mito de Abraão em muito se pareceria com Caim.

\section{V- Viajantes da História}

Imaginou-se, na discursiva anterior, que no instante do ato crucial em que Abraão decidiu-se por sacrificar seu filho Isaac, Camus e Saramago absurdamente transitavam próximos aquela cena, como dois observadores atentos aos limites existenciais do velho patriarca. Como dois viajantes do tempo, que desembocaram nas alturas do Moriá sob o pretexto de levar a júri aquele feito indigesto, sem precedentes capazes de justificá- 
lo, e enfim corrigir o engano milenar que coroou Abraão pai da fé. Camus e Saramago presumivelmente julgaram pelo mesmo parecer, ou seja, Abraão premeditou a morte do filho, e de certo o faria quando, inesperadamente, fora impedido. A natureza do que o impediu não importava tanto assim aos observadores, que anotavam aos blocos cada sintoma da mente atormentada daquele homem. Não havia dúvidas, Abraão era culpado, senão como assassino ao menos o seria como louco! Violara o dever visceral de um pai e, ensandecido, degolaria o filho como a um burrego de seu rebanho. O deixaria queimar, e assim cairia nas graças do seu Deus. Condenado - diriam os juízes do futuro - por abandonar a ética sem motivos razoáveis.

Saramago acusa também aquele que ditou a ordem assassina, Deus. Acusa-o de sadismo, de torturar aquela família com seus caprichos misteriosos - e o faria novamente com o pobre Jó. De levar à loucura, e ao desespero, aquele velho tolo impressionável. A história foi enfim corrigida, o crime julgado, o certo e o odiento postos em seus devidos lugares.

Juízos tais como estes - conclusões modernas e pós-modernas sobre o mito de Abraão - foram tratados antecipadamente por Kierkegaard. Ele sabia muito bem que a ventura de Abraão não poderia ser compreendida por nenhum transeunte da história, pois justamente neste inexplicável paradoxo reside a constituição exemplar da fé de Abraão. Aliás, a contestação era totalmente lógica e perde a razão aquele que não a fez; no limiar da heresia - fazendo lembrar a irreverência de Saramago - Kierkegaard recoloca a questão: "Hegel não tem razão ao falar da fé; perde a razão por não contestar, alto e bom som, o facto de Abraão gozar de honra e glória como pai da fé; ao passo que devia ser apresentado a tribunal e denunciado como assassino" (KIERKEGAARD, 2009, p. 113). Em síntese, o caminho primeiro para entender o mito abraâmico é, outra vez, contestá-lo - o que até aqui foi feito por este artigo.

Assim, Kierkegaard distingue Abraão dos heróis trágicos, pois, diferente destes últimos, o patriarca movia-se seguramente pela força do 
absurdo (KIERKEGAARD, 2009, p. 115). Nas narrativas homéricas, um de seus exemplos, Agamêmnon sacrifica aos deuses sua filha. Ele tinha em vista, entretanto, os ventos favoráveis que soprariam suas naus na direção da guerra e, por assim dizer, da glória do povo grego. Crível ou não, virtuoso ou vulgar, este sacrifício se faz compreensível a qualquer viajante da história, pois "o herói trágico permanece ainda dentro do ético" (KIERKEGAARD, 2009, p. 118), pontua o filósofo. Embora obscureça a relação entre pai e filha, o episódio de Agamêmnon enaltece um fim que é de interesse do povo, o que faz do ato trágico também um ato heroico. Isso não se aplica a Abraão, no entanto. Nada dentro dos parâmetros humanos poderia justificá-lo, nada o livra da monstruosidade do seu ato. Seu feito excede o ético, de modo a torná-lo deveras absurdo.

Restou àquele velho pai somente o silêncio abafado da jornada trágica, pois como se expressaria? Quem o compreenderia? Nada do que dissesse faria sentido, uma vez que os homens se expressam na esfera do universal, do ético-racional, qualquer uma de suas palavras excederiam tais fronteiras para incorrer, outra vez, no absurdo indefensável da fé. O caminho de Abraão estreitava-se para um homem só, para um fazer solitário. Aqueles que - neste vasto mundo da imaginação literária - o acompanhassem não suportariam o peso dilacerante daquele paradoxo e de certo, presume o autor, "Não é possível chorar por Abraão. Aproximamo-nos dele com um horror religiosus, como Israel se aproximou do monte Sinai” (KIERKEGAARD, 2009, p. 120).

O horror religioso que assalta o leitor atento, ante a narrativa abraâmica no decorrer dos séculos, tomou em susto a sensibilidade moderna de autores como Camus e Saramago, fazendo-os trêmulos acossados pela força do paradoxo. Na fuga do inominável, restou-lhes rechaçar a face obscura do irracional com violência e destreza literária. Seguindo um rastro kierkegaardiano, a jornada de Abraão torna-se incompreensível devido à força religiosa do irracionável que salta o texto no decurso das eras.

Num afluente inverso, Kierkegaard também treme ante o horror en- 
carnado naquela primitiva incoerência - o pai prestes a sangrar seu filho -, porém, marchando avesso ao racionalismo, assume a narrativa do patriarca hebreu como modelo inconteste do que ultrapassa os parâmetros da reflexão, do racionalizável, e do pensamento hegeliano que acredita tudo explicar. O erro recorrente que torna Abraão inapreciável para quem o observa eticamente, e ao mesmo tempo elogiado de forma demasiadamente impensada por alguns religiosos, é olhá-lo tão somente por lentes teóricas, sem o envolvimento imbricado àquela investida de fé. É como se o pensamento fosse inadequado quando se trata de mediar o acontecimento da fé. Este escopo kierkegaardiano tenta realocar a fé à parte de qualquer intermediário, de qualquer racionalização, o que a mantém paradoxal, acresce ele:

A fé consiste precisamente no paradoxo de o singular enquanto singular ser superior ao universal, estar justificado perante ele, não ser seu subordinado [...] Este ponto de vista não pode ser mediado; pois toda a mediação acontece precisamente por força do universal; é e permanece para toda a eternidade um paradoxo, inacessivel ao pensamento (KIERKERGAARD, 2009, p. 114).

Outro equívoco - comum no contexto protestante no qual o autor se insere - é não ater-se ao princípio e ao desenlace da história - lê-la como se lê um manual - e julgá-la admirável apenas pelo seu desfecho. A abstração que não permite adentrar com a devida seriedade no drama desta história - acompanhar Abraão monte acima - "omite a adversidade, a angústia, o paradoxo" (KIERKEGAARD, 2009, p. 123). E, destituído de seu paradoxo, da ética que o tentou para que desistisse, - ou da angústia de erguer-se contra quem ama na espera absurda de tê-lo de volta, sem saber ao menos explicar "o como" ele the seria devolvido sem a adversidade insolúvel daquela escolha Abraão seria outro entre tantos pais que, naqueles dias, queimavam seus filhos para saciar deuses famintos.

Ademais, sua grandeza consiste em suportar o paradoxo do seu ato, a saber, acreditar no absurdo de reaver Isaac estando prestes a sacri- 
ficá-lo. Tal absurdidade insana, esta loucura, o moveu até o fim de sua provação. Ora, ao certo ninguém que o observava poderia entendê-lo, nem mesmo escritores geniais como Camus ou Saramago, pois "é por força do absurdo que pode reaver Isaac. Em momento algum, portanto, é Abraão herói trágico, é antes algo completamente diferente: ou um assassino ou um crente" (KIERKEGAARD, 2009, p. 115). A fé de Abraão consiste neste paradoxo: ele sacrifica o finito para obter o infinito à espera que o finito Ihe seja devolvido. Do substrato do Absurdo irrompe sua fé inegociável. Ela é, portanto, inapreensível do ponto de vista do racional, e, visto por estes olhos da pura razão, não foi outro senão um assassino o pai da fé.

O mito de Abraão suscita horror, ao mesmo tempo em que fascina pela sua grandeza. A desproporção destas reações em cada leitor, ao logo do tempo, fez-lho exemplar, para a crença ou para descrença em Deus.

\section{VI- Conclusão - Sedução, Suspeita e Aversão}

Fitando as alturas de uma fé abraâmica, ou seja, visando à superação das camadas estéticas e éticas da existência, Kierkegaard ressuscitou a presença do irracional, esta força esquecida, recôndita no fundo das pretensões do racionalismo ou das aparências religiosas tão bem harmonizadas com a vida em sociedade. Kierkegaard está entre os primeiros a desfigurar as ilusões modernas - desnudar a fragilidade do pensamento - e perturbar a hipocrisia religiosa burguesa de seu século. Corroeu, pouco a pouco, a pureza da razão erigida tão perfeitamente pelos seus antecessores, e isto o fez ironicamente através da fé, ou ainda, do irracionável a ela atrelado. A fé exemplar de Abraão - encontradiça fora e além dos parâmetros ético-racionais - serviu-lhe no ataque que faria ruir a pretensiosa razão na modernidade. Muitos outros pensadores seguiram pelas frestas e rachaduras que Kierkegaard abriu no monumento da razão, entre eles o já tardio Camus reconheceu-se herdeiro deste legado, ele diz um século mais tarde: "Essa razão universal, prá- 
tica ou moral, esse determinismo, essas categorias que explicam tudo fazem o homem honesto dar risada" (CAMUS, 2013a, p. 33-34).

Kierkegaard reconheceu a incoerência primeira, o imenso vazio de sentido e de razoabilidade da vida, e a tudo isso Camus chamou de Absurdo. Todavia, neste ínterim kierkegaardiano - após o esvaziamento de todas as instâncias da existência desde o estético ao ético - após tudo resignar, como ocorrera com Abraão, o indivíduo encontra-se a um salto de distancia da fé. O cavaleiro da fé se ergue por sobre o Absurdo em que fora plantado e o ultrapassa, encontrando assim um sentido fora do mundo - além das medidas humanas e racionais. É a ida ao infinito com retorno marcado ao finito.

Camus conversa com Kierkegaard tão somente durante a travessia do deserto existencial - no reconhecimento do desespero do homem e do Absurdo da existência - no entanto quando Kierkegaard ousa cruzar as fronteiras deste deserto, quando ousa saltar para fora dele num voo apaixonado em direção ao irracional, Camus titubeia e permanece no limiar da razão. Sabia ele que a razão era limitada, entretanto, fora dela também não havia esperança. Saltá-la incorreria no suicídio filosófico.

Kierkegaard fora, afirma Camus, aquele que contemplou o Absurdo em sua face mais real e mais bravia, ele fragmentou os absolutos e multiplicou as contradições. Nem a moral - que assumira um lugar privilegiado no pensamento racional - foi poupada pelas assertivas kierkegaardianas. O exemplo de Abraão foi a agulha com a qual provocou a razão, assim pôde argumentar sobre a existência de imperativos que superam até mesmo a ética.

Antes da jornada espiritual sugerida em Kierkegaard, Camus encontrara nele uma testemunha do Absurdo, alguém que como ele viu um mundo ainda informe e vazio, onde as luzes do racionalismo não sabiam iluminar. No entanto, Camus peregrinou solitário neste deserto do Absurdo, pois Kierkegaard - como tantos outros existencialistas a seu ver - incorrera no suicídio filosófico. Sacrificou, ao lado de Isaac, sua 
razão nos altares do imponderável. Não suportara viver naqueles ares pestilentos do desespero e, para calar o Absurdo com as rosas da ilusão, Kierkegaard escapou ao desespero. Embora Abraão retorne para casa trazendo outra vez Isaac vivo, pouco antes, estava absorvo no completamente insano, a mercê da loucura e tentado pelo ético. Esta coragem de perder-se dessa forma - apaixonadamente levado pelo irracional - esta confiança resignada, para Kierkegaard, estabelece a fé e reconcilia os homens com seu mundo. Para Camus esta é a coragem de um suicida que, incapaz de atentar contra o corpo, sacrifica seu intelecto. Destarte, o homem lúcido é aquele que aprendeu a não temer o desespero.

O passo de Kierkegaard em direção ao Absurdo foi seguido, mais tarde, por Camus. Todavia, este último se nega acompanhar Abraão em sua caminhada absurda e, nas extremidades do Moriá, recusa-se ao salto de fé kierkegaardiano para deixar-se ceder propositalmente, e inequívoco, à tentação ética que atribulou aquele pai. Camus permanece, a todo custo - embora açoitado pelo desespero -, nas camadas éticas da existência sem atrever-se nem sequer um passo depois delas. Abraão deixara-se levar, em deslumbramento, possuído pelo mistério até o lugar onde sacrificaria o próprio filho, Camus hesitou ante o caminho escuro da fé. Nas margens rasas da razão Camus resiste ao estágio religioso, e por assim dizer sentencia Abraão e seu mais ávido defensor, Kierkegaard, acusa-os do abandono da ética e do suicídio da razão respectivamente.

Por sua permanência ética, e por não reduzi-la em nenhuma hipótese - nem sob as ordens de Deus - Camus se aproxima do tino literário do português, também romancista, José Saramago. Aparentados pela revolta metafísica, Camus e Saramago negam o mistério divino em nome de um valor moral. Ambos tomam partido dos homens e, para tanto, lhes ocorrera desafiar o Deus bíblico e seus ditames antiéticos. Enquanto Camus nega o salto religioso, seu herdeiro mais jovem, Saramago, alça à revelia e - não apenas nega o salto Kierkegaardiano - impele ousadamente o retorno do homem religioso ao estágio ético da existência. 
Saramago chama os crentes ao arrependimento, convoca-os de volta ao esclarecimento e aos princípios do humanismo.

Saramago passeia pela bíblia, especialmente por seu Primeiro Testamento, levado pela rebeldia de seu personagem, Caim. Ele toca, com maior insistência, neste imperativo divino, dado a Abraão, que levanta um pai contra o filho. $E$, indo deveras além das prerrogativas camusianas, Saramago não apenas recusa-se a "saltar" por falta de razoabilidade, ele também nega Deus, incisivamente, através de critérios éticos.

Tem-se, finalmente, entre Kierkegaard e Saramago, perpassando indesviavelmente por Camus, três gradações de percepção da metafísica cristã. A primeira delas é harmônica, e retorna a Kierkegaard e ao seu duelo com a razão hegeliana. Como Prometeu desafiou os deuses de outrora, Kierkegaard erguera-se em defesa do irracional tho reconhecendo nas origens e nas tessituras da existência. A imensidade deste "mistério tremendo", entrementes, o seduziu. Ele encontrara nesta desmedida sagrada as medidas de sentido para existência e a cura para o desespero. Em termos camusianos, ele fugiu ao Absurdo e enfim fora reconciliado.

A percepção metafísica de Albert Camus singulariza, como numa moldura vazia, o silêncio de Deus. Esta ausência displicente suscita suspeita e revolta. Camus, como Kierkegaard, também principia pelo reconhecimento do Absurdo alastrado nas veredas da existência, porém, como que acorrentado por vontade, ele não pretende saltá-lo em nenhuma hipótese. Prefere o desespero à ilusão e suspeita daquilo que lhe é irracionável. Sabe dos limites da razão, porém sabê-la limitada não implica necessariamente em rejeitá-la. Camus não nega nem afirma a existência de Deus - pois a negação já é em si uma forma de afirmação - porém o recusa como quem não deseja fundar sua vida por sobre um mistério abismal. A ética é o limiar camusiano, portanto, em favor dos homens, ou em favor de Isaac, Camus rejeita a adesão obstinada ao irracional.

Em Saramago, a terceira gradação de olhar metafísico, o para- 
doxo absurdo da existência - sua razão pueril - permanece como em Kierkegaard ou em Camus, porém, desta vez conota ainda mais pessimismo literário e desemboca na total descrença em Deus. Nas intuições deste ateísmo agressivo, Saramago encontra nas escrituras bíblicas apenas a existência literária de um Deus essencialmente mau. Como num processo de divórcio existencial com Deus, após a paixão de Kierkegaard, a suspeita de Camus, o irracional será totalmente repelido por Saramago.

Tendo em mãos o legado filosófico camusiano e o notável romance Caim, foi possível transpor José Saramago e Albert Camus, como viajantes do tempo, para o dramático percurso que Abraão fizera com seu filho Isaac. Como qualquer transeunte da história, Camus e Saramago condenariam Abraão pelo abandono do ético. Kierkegaard, por sua vez, à luz de Temor e Tremor, antecipou tais sentenças e as julgou insatisfatórias, pois sabia que fora daquela relação absoluta com o Absoluto Abraão não poderia de fato ser compreendido. Nenhuma teoria, por mais próxima que esteja daquele momento, aclararia aquele ato com a precisão exigida pela modernidade, e isto Kierkegaard bem o sabia. O que restou às ciências humanas, e o que este artigo tentou ousar, são aproximações, comparações e rememorações instrutivas - isto com o devido temor e tremor.

\section{Referências Bibliográficas}

BÍBLIA. Português. Bíblia sagrada. Tradução de João Ferreira de Almeida. 2a edição. Barueri: Sociedade Bíblica do Brasil, 2011. Edição revista e atualizada no Brasil.

CAMUS, Albert. A peste. Tradução de Valerie Rumjanek. 22a edição. Rio de Janeiro: Record, 2013c.

CAMUS, Albert. O avesso e o direito. Tradução de Valerie Rumjanek. 3a edição. Rio de Janeiro: Record, 1996.

CAMUS, Albert. O homem revoltado. Tradução de Valerie Rumjanek. 10ạ edição. Rio de Janeiro: Record, 2013b.

CAMUS, Albert. O mito de Sísifo. Tradução de Ari Roitman e Paulina Watch. 3a 
edição. Rio de Janeiro: BestBolso, 2013a.

DOSTOIÉVSKI, Fiódor. Os irmãos Karamázov. Tradução de Paulo Bezerra. 3ạ edição. São Paulo: Editora 34, 2012.

GOUVÊA, Ricardo. Paixão pelo paradoxo: uma introdução a Kierkegaard. São Paulo: Novo Século, 2000.

KIERKEGAARD, Søren. Temor e tremor. Tradução de Elisabete M. de Sousa. Lisboa: Relógio D'Água, 2009.

KIERKEGAARD, Søren. O desespero humano. Tradução de Adolfo Casais Monteiro São Paulo: Editora UNESP, 2010.

NIETZSCHE, Friedrich. A Gaia Ciência. 2a edição. Tradução de Rubens Rodrigues Torres Filho. São Paulo: Abril Cultural, 1978.

SARAMAGO, José. Caim. 3a edição. São Paulo: Companhia das Letras, 2009.

TILLICH, Paul. Dinâmica da fé. Tradução de Walter O. Schlupp. São Leopoldo: Sinodal, 1985. 